
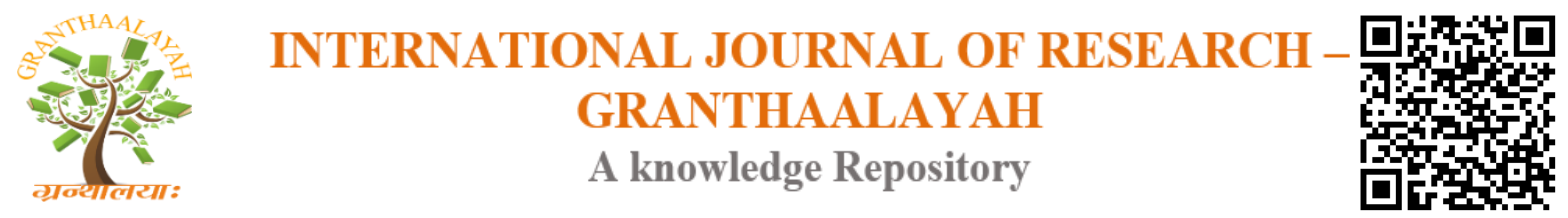

Management

\title{
IMPACT OF AUTOCRATIC LEADERSHIP STYLE ON JOB PERFORMANCE OF SUBORDINATES IN ACADEMIC LIBRARIES IN PORT HARCOURT, RIVERS STATE, NIGERIA
}

\author{
Kalu Dolly C ${ }^{1}$, Okpokwasili Nonyelum P. *2 \\ ${ }^{1}$ Librarian II, The Library, Rivers State University, PMB 5080, Nkpolu-Oroworukwo, Port \\ Harcourt, Nigeria \\ *2 Associate Professor, Department of Library and Information Science, Faculty of Education, \\ Rivers State University, PMB 5080, Nkpolu-Oroworukwo, Port Harcourt, Nigeria
}

\begin{abstract}
The study focused on the impact of autocratic leadership style on job performance of subordinates in academic libraries in Port Harcourt, Rivers State, Nigeria. The research design was a survey. The respondents were the 74 professional and para-professional staff working in the libraries studied. Data collection was through questionnaire. instrument titled "Autocratic Leadership Style on Job Performance of Subordinates in Academic Libraries (ALSJPSAL)" consisting of five (5) item statements. Analysis was done using frequency and mean for the research question. Findings of the study revealed that autocratic leadership style tends to develop dependent and uncreative subordinates who are afraid to take up responsibility. Autocratic leadership style, however, shows a significant negative impact on employee performance. This style of leadership tended to have work groups that were less productive and subordinates showed a high degree of dissatisfaction on the job. Therefore, autocratic leaders tend to limit the performance of subordinates. It is recommended that autocratic leadership style may be very valuable in situations where decisions need to be made as quickly and decisively as possible. Since autocratic leadership style leads to job dissatisfaction of subordinates, library heads should be closely monitored by the parent institution to check their excesses.
\end{abstract}

Keywords: Autocratic Leadership Style; Job Performance; Subordinates; Academic Libraries; Rivers State; Nigeria.

Cite This Article: Kalu Dolly C, and Okpokwasili Nonyelum P.. (2018). "IMPACT OF AUTOCRATIC LEADERSHIP STYLE ON JOB PERFORMANCE OF SUBORDINATES IN ACADEMIC LIBRARIES IN PORT HARCOURT, RIVERS STATE, NIGERIA.” International Journal of Research - Granthaalayah, 6(10), 212-220. 10.29121/granthaalayah.v6.110.2018.1187.

\section{Introduction}

The library plays a paramount role in this challenging and changing world where the economy is knowledge-based; by the provision, processing, packaging, preservation and dissemination of 
information resources. The success of the library in achieving these roles effectively rest upon the leadership of the library. The word leadership has been used in various aspects of human endeavours such as politics, business, academics and social works. A leader is a person who takes the central roles in interaction and who influences the behavior of other members of a group. Fatokun, Salaam, Ajebomogun and Adidipe (2010) described a leader as an individual who has authority over others and who is responsible for guiding their actions. In academic libraries, university and college/polytechnic librarians are the managers of the libraries and will be described as leaders in this work.

Leadership has, however assumed greater importance in today's organization including the library because of emerging force of globalization, technological innovations and workers expectations (Nwaigwe, 2015). These forces require dynamic and efficient leadership, anchored on strong ability to, not only combine resources in the most efficient ways, but to build a formidable work force that will work with enthusiasm for the achievement of goals. Leadership involves inducement; persuasion and motivation of subordinates to enable them contribute willingly to the organizational goals based on the employee's maximum capabilities (Nwachukwu, 2010).

Stodgill (1974) in a survey of leadership theories and research argue that, "there are almost as many different definitions of leadership as there are persons who have attempted to define the concept". Stodgill's statement points directly to the fact that leadership as a managerial technique or skill is becoming very important to the manager particularly in a developing context. Leadership is defined as the process of directing and influencing the task-related activities of group members. This definition has three important elements. Firstly, every leadership situation involves peopleleaders and followers or subordinates by the voluntary consent or willingness to follow the leader and make leadership process possible. Secondly, all leadership situations involve unequal distribution of power between the leader and the group members (subordinates). Because of unique; distribution or power, the leader has to give command and subordinates are bound to obey. If all members within the group share power equally, then we can possibly refer to the group as a leaderless one. Every group must have a leader. The distinguishing factor between a leader and members of a group is the fact that the leader has superior powers as opposed to members of the group. Thirdly, leaders must have some unique qualities that should make them be able to influence the activities of group members. This kind of influence should however, revolve around behaviours that have to positively change the work attitude of subordinates.

In libraries, like any other organization, there are leaders whose behaviour and personality traits influence others to perform their legitimate duty. In other words, leaders must possess style which enable them to achieve desired goals through proper co-ordination and direction of the path goal. These styles determine, to a large extent, what leaders see and how they respond to situations around them. The influence of any style of leadership on the workforce, especially on the subordinate librarians will be bearable if the library leadership will achieve set goal. This is because followers are influenced when leadership and followership are properly linked (Vecchio, 2007). And in this respect, the subordinate job performance of librarians comes to bear to properly link leadership in academic libraries.

A manager can increase has contribution towards employee's performance by role perception. How he sees himself as leader determines how he can influence his subordinates. The chief 
librarian as the leader in the academic library should have a peculiar style of leadership that will yield productivity and enhance the performance of his or her subordinates. There are different leadership styles adopted by leaders of academic libraries in Rivers State and which would have their impact on subordinates' job performance in these libraries.

Mgbodile (2004) states that despite the varying terminologies used by experts to describe management styles of leadership, it has been generally agreed that style used by men in leadership position can be put into three main types; autocratic, democratic and liassez-faire leadership styles. Each of these leadership styles has impact on subordinate job performance in the library. This paper will dwell on the autocratic form of leadership.

\section{Statement of the Problem}

The impact of leadership in the overall success of the organization (libraries inclusive) cannot be over emphasized. Many libraries have not been able to attain the set goals due to problem arising from leadership styles adopted. Therefore, for progress to be recorded in organizations, there must be a leader to direct and coordinate the activities of group members of the organization to ensure conformity with the policies. In the library, like other organizations, leadership style has effect on the job performance of subordinates, who are the "engines" saddled with the task of bringing library vision and mission into reality. A good understanding of the impact of autocratic leadership style on subordinates' job performance is vital in supporting human resources development in libraries and key factor in determining the success of both the head librarian as a leader, his subordinate librarians and the library organization. Changes in the political, economic and technological spheres may call for changes in leadership styles. The low or high job performance of subordinate librarians may be attributed to the autocratic leadership style adopted by the head librarian. This is what this study seeks to find out.

This research is limited to how autocratic leadership style affects the job performance of employees of academic libraries in Rivers State. Though there are many academic libraries in Port Harcourt, Rivers State, this study was carried out in these four (4) academic libraries in Rivers State as follows: University of Port Harcourt Library; Rivers State University Library, Port Harcourt; Ignatius Ajuru University of Education Library, Port Harcourt and Captain Elechi Amadi Polytechnic Library, Rumuola, Port Harcourt. This study is aimed at unveiling the impact of autocratic leadership style on job performance of subordinates in academic libraries in Rivers State.

\section{Research Question}

- To achieve the purpose of this study, the following question was posed to guide and direct the study:

- What is the impact of autocratic leadership style on job performance of subordinates in academic libraries in Rivers State?

\section{Review of Related Literature}

In autocratic style of leadership, the leader is the sole determinant of what is done: his main contact with his subordinate occurs when he is giving them instructions. It is a very popular style among 
manager commanding subordinates and it is still used around the world. This style basically comes natural to many leaders and brings many benefits, thus many managers start to lead using this style and try to improve on it when pursuing their own development. The style is used when leaders inform their employees what they want done and how they want it attained, without being advised by their followers. Excessive use of authority will decrease productivity in the long-term in the academic library. People either get fed up and leave or fall into malice without creativity and innovation. This style got work done through fear and this style of leadership tells workers what to do and how to do it (Ajibade, 1990).

Janse (2018) posited that authoritarian leadership is a now outdated form of management that, especially in recent decades, is sure to create a lot of resistance among employees. The word authoritarian comes from the Greek language and derives from the word autocratic. 'Auto' means self and 'cratic' means rules. Autocratic leadership is a leadership style in which, without accepting participation, the authoritarian leader makes all the decisions themselves and delegates the tasks. This leader will check and punish their employees more severely and quickly. When the results are disappointing, or when the leader expects this to happen, the authoritarian leader will use his power to threaten sanctions such as dismissal so that undesirable behaviour can be prevented (Janse 2018). The authoritarian leader prefers to focus on results and tasks rather than on the employees who make the results possible. This supreme ruler assumes that employees have little ambition, prefer to avoid responsibility and only strive for individualist goals. This way of thinking ensures that the leader tolerates little feedback, does not enter into discussions and always maintains control (Janse 2018). This leadership style is therefore often assessed as unpleasant, dominant and insensitive. The anti-social skills possessed by the authoritarian leader often lead to resistance among employees because they feel subordinate. The feedback this leader gives to their employees is often negative, not very constructive and is sometimes accompanied by overt anger (Janse 2018).

\section{The Effects of Autocratic Leadership Styles are as Follows (Janse, 2018)}

\section{Lack of Creativity}

Because the authoritarian leader decides everything themselves and executes it in their own way, they don't give the employees the chance to give their spin on the tasks to be performed. This way, the creative ability of the employee is never developed or discovered and that is a missed opportunity for both the employee and the company. After all, creativity stimulates growth and innovation within an organisation and also ensures increased productivity. The need that every person has to do meaningful work is also satisfied by developing creativity on the work flow.

\section{Demotivating}

The demotivating feeling that occurs among people who work under an authoritarian leader is partly due to the lack of creative development and partly due to fear of sanctions. The fear of sanctions causes them to be extrinsically negatively motivated. The demotivating circumstances ensure that people under an authoritarian leader often walk away from it. Employees know that they have to carry out the orders they receive without contradiction, which means they will never do more than is necessary.

\section{Lack of a Sense of Responsibility}

This effect also comes from an authoritarian leadership style. The employees feel like they're just a number, without value, because their input is cut off or not even heard. When they achieve 
success, they are not or barely appreciated by the authoritarian leader, while they get a thorough scolding when things go less well. This also removes the bond of trust between the leader, and the employees will never tell him anything in confidence.

\section{Passive Aggressiveness}

The frustration and fear that arise from authoritarian leadership can take on unpleasant forms. The dominance that is strongly present among authoritarian leaders creates resistance. Because the group members constantly have to comply, they become angry and uneasy. There's no room for these sorts of feelings under an authoritarian leader, which means they often express these feeling to weaker people within the team or at home to family and friends. The same happens, for example, in education, where students express the pent-up aggression, which they build up with a strongly authoritarian teacher, to younger or milder teachers.

Autocratic leadership represents all those leaders who makes decision without the consent of team members and is usually applied when quick decision is be taken and team agreement is not important for acquisition of successful results (Boehm, Dwertmann, Bruch and Shamir, 2015). Little opportunities are given to staff and team members to make suggestions, even if it is in the best interest of the team or organization (Amanchukwu, Stanley and Ololube, 2015). An autocratic leader mostly makes selection on the basis of their own judgments and ideas that rarely include followers' advice and these leaders have absolute control over the group (Zareen, Razzaq, \& Mujtaba, 2015). According to Iqbal, Anwar \& Haider (2015), autocratic leaders give orders without explaining the reasons or future intentions.

In the review of work, there were studies on autocratic leadership style, subordinates' job performance but the combined study of these concepts is lacking. This is the gap in knowledge this study will try to fill.

\section{Methodology}

Survey design was employed in this study. Aina and Ajiferuke (2002) stated that survey research involves systematic and comprehensive collection of information about the opinions, attitudes, feelings, beliefs and behaviour of people. The collection is often accomplished through the use of questionnaire, interview - another data collecting instruments. The decision to use this design was borne out of the fact that the survey focused on sample population of autocratic leadership style and its impact on subordinate job performance in academic libraries in Rivers State.

The institutions studied are all located in Rivers State which is one of the thirty-six (36) states in Nigeria and was created on $27^{\text {th }}$ May 1967. The capital of Rivers State is Port Harcourt. Interestingly, Port Harcourt is the largest city and is economically significant as the centre of Nigeria's old industry. The State was created in 1967 with the split of the Eastern Region of Nigeria. Until 1996, the State contained the area which is now Bayelsa State. Rivers State is famous for its vast reserves of crude oil and natural gas.

Prior to the discovery of oil in commercial quantity in 1958, agriculture was the primary occupation of the people of Rivers State. This was due to its abundant palm oil and kernel which basically constituted the main revenue source of the country. Rivers State is one of the leading states in the production of yam, cassava, cocoyam, maize, rice and beans. Besides being lucrative, 
fishing is also a favourite past time activity. The State provides valuable seafood's such as crabs, oysters, shrimps and sea snails.

University of Port Harcourt located in Choba, Port Harcourt established by the Federal Government in 1975, the Rivers State University, Port Harcourt founded in 1980 by the State Government; the School of Health Technology, Port Harcourt, established by the state government; the Federal College of Education (Technical), Omoku; and the state-owned Rivers State Polytechnic at Bori; the Rivers State University of Education (Ignatius Ajuru University of Education) at Rumuolumeni, Nkpolu-Oroworukwo and Ndele; and the School of Nursing and Midwifery at Rumeme, Port Harcourt and The Captain Elechi Amadi Polytechnic, Port Harcourt, Rivers State.

All these schools mentioned above, ranging from universities to colleges have existing and functional academic libraries and are of immense help in the course of this research which prompted the researcher to survey them with particular interest in their autocratic leadership style and impact on subordinates' job performance.

The population of the study is 74. This comprises of all the professionals and para-professionals of the academic libraries studied. There is well-structured line of authority and they met the researcherls specification, they are all located in Port Harcourt. These are University of Port Harcourt library with a population of 41 (22 professionals and 19 para-professionals); Rivers State University 16 (11 professionals and 5 para-professionals) Ignatius Ajuru University of Education Library 10 (7 professionals and 3 para-professionals) and Captain Elechi Amadi Polytechnic Library, 7 ( 3 professionals and 4 para-professionals). The entire population of 74 was used as sample for this study since it is not too large and can be conveniently managed by the researchers. The census enumeration sampling technique was adopted because the population is small.

The study used questionnaire instrument titled "Autocratic Leadership Style on Job Performance of Subordinates in Academic Libraries (ALSJPSAL)" consisting of five (5) item statements. as the basic research instrument, which is a collection of questions, put together to answer the research question. The questionnaire consists of the questions asked to seek respondents' opinion on the various item statements of the subject of study. A five- point Likert scale questionnaire was developed to provide the respondents ease of answering the questions as per their level of agreement (McLeod, 2008). The Likert scale follows the format of: 1) Strongly Agree (SA); 2) Agree (A); 3) Disagree (D) and 4) Strongly Disagree (SD).

The face validity of the instrument was determined by two experts in Library and Information Science, and Educational Measurement and Evaluation who examined the purpose of the study and research questions alongside with each item of the instrument in order to determine whether the instrument actually measured what it is supposed to measure. The observations made by the experts were used to effect necessary corrections on the instrument before it was final administered to the respondents.

The reliability of the instrument was trail-tested at Imo State University, Owerri Library. This institution was selected because it is outside the area of the study. In this regard, 6 respondents were randomly selected from staff. Split-half method was used to test the reliability of the 
instrument. The $\mathrm{X}$ was for odd numbers while $\mathrm{Y}$ was for even numbers. Their responses were analysed using the Pearson Product Moment Correlation (PPMC). The correlation coefficient (r) is 0.94 . This shows that the instrument is very strong and reliable to gather data for the study.

The researchers personally administered the data collection instrument to the respondents with the help of the library staff that work in the libraries studied. Four (4) weeks were used for the administration and collection of the instrument. This enabled the researchers have enough time to cover all the institutions.

\section{Data Analyses and Interpretation}

\section{Data Analyses Based on Research Question}

Research Question: What is the impact of autocratic leadership style on job performance of subordinates?

Table 1: Impact of Autocratic Leadership Style on Job Performance of Subordinates (N=74)

\begin{tabular}{|c|c|c|c|c|c|c|c|c|c|}
\hline \multirow[t]{2}{*}{$\mathbf{S} / \mathbf{N}$} & \multirow{2}{*}{\multicolumn{2}{|c|}{ Items Statement }} & \multicolumn{4}{|c|}{ Categories } & \multirow{2}{*}{$\begin{array}{l}\text { Total } \\
\text { Score } \\
\mathbf{x x x}\end{array}$} & \multirow{2}{*}{$\begin{array}{c}\text { Mean } \\
(\bar{x})(\text { Total } \\
\text { Score } \div 74)\end{array}$} & \multirow[b]{2}{*}{ Remarks } \\
\hline & & & $\begin{array}{l}\text { SA } \\
(4)\end{array}$ & $\begin{array}{l}\text { A } \\
(3)\end{array}$ & $\begin{array}{l}\mathrm{D} \\
(2)\end{array}$ & $\begin{array}{l}\text { SD } \\
\text { (1) }\end{array}$ & & & \\
\hline \multirow[t]{2}{*}{1} & \multirow{2}{*}{$\begin{array}{l}\text { It breeds counter forces } \\
\text { of antagonism and } \\
\text { restriction of output }\end{array}$} & Freq. & 10 & 11 & 34 & 19 & \multirow[b]{2}{*}{160} & \multirow[t]{2}{*}{2.16} & \multirow[t]{2}{*}{ Negative } \\
\hline & & Score & 40 & 33 & 68 & 19 & & & \\
\hline \multirow[t]{2}{*}{2} & \multirow{2}{*}{$\begin{array}{l}\text { Frequently results in } \\
\text { hostile attitudes to work }\end{array}$} & Freq. & 11 & 16 & 28 & 19 & \multirow[b]{2}{*}{167} & \multirow[t]{2}{*}{2.26} & \multirow[t]{2}{*}{ Negative } \\
\hline & & Score & 44 & 48 & 56 & 19 & & & \\
\hline \multirow[t]{2}{*}{3} & \multirow[b]{2}{*}{$\begin{array}{l}\text { Tends to develop } \\
\text { dependent and } \\
\text { uncreative employees } \\
\text { who war afraid to seek } \\
\text { responsibility }\end{array}$} & Freq. & 22 & 15 & 20 & 17 & \multirow[b]{2}{*}{190} & \multirow[t]{2}{*}{2.57} & \multirow[t]{2}{*}{ Positive } \\
\hline & & Score & 88 & 45 & 40 & 17 & & & \\
\hline \multirow[t]{2}{*}{4} & \multirow{2}{*}{$\begin{array}{l}\text { Leads to distorted and } \\
\text { guarded communication. }\end{array}$} & Freq. & 10 & 12 & 26 & 26 & \multirow[b]{2}{*}{158} & \multirow[t]{2}{*}{2.14} & \multirow[t]{2}{*}{ Negative } \\
\hline & & Score & 44 & 36 & 52 & 26 & & & \\
\hline \multirow[t]{2}{*}{5} & \multirow{2}{*}{$\begin{array}{l}\text { Subordinates are } \\
\text { preoccupied with rules } \\
\text { and procedures, }\end{array}$} & Freq. & 21 & 24 & 17 & 12 & \multirow[b]{2}{*}{202} & \multirow[t]{2}{*}{2.73} & \multirow[t]{2}{*}{ Positive } \\
\hline & & Score & 84 & 72 & 34 & 12 & & & \\
\hline
\end{tabular}

Researchers' Field work 2017; Criterion Score $=2.50$

Table 1 presents data from responses by respondents on impact of autocratic leadership style on the job performance of subordinates. Items 1-5 are the different statements pertaining to the variable; autocratic leadership style under the four categories of Strongly Agree (SA), Agree (A), Disagree (D), and Strongly Disagree (SD). Analysis in Table1 indicated that items 1 (It breeds counter forces of antagonism and restriction of output), 2 (frequently results in hostile attitudes to work and 4 (leads to distorted and guarded communication) were rated negative as the impact of autocratic leadership style on job performance of subordinates. This is because their mean scores of $2.16,2.26$ and 2.14 respectively were not up to the cut off mean of 2.50 . However, items 3 (tends to develop dependent and uncreative employees who was afraid to seek responsibility) and 5 (subordinates are preoccupied with rules and procedures) were rated positive with mean scores of 2.57 and 2.73 respectively. 
Respondents, according to analysis in Table 1, accepted that autocratic leadership style has impact on the subordinates in that it tends to develop dependent and uncreative employees who are afraid to seek responsibility and subordinates being preoccupied with rules and procedures. This implies that subordinates do not make inputs but act only based on instructions given by the leader. This limits the creativity and initiative of the subordinates. In support of this Ajibade (1990) opines that this style is used when leaders inform their employees what they want done and how they want it attained, without being advised by their followers. Excessive use of authority will decrease productivity in the long-term in the academic library. People either get fed up and leave of fall into malice without creativity and innovation. This style got work done through fear, and this style of leadership tells workers what to do and how to do it. John (2002) opines that power and decision making reside in the autocratic leader who directs the group members on the way things should be done and does not delegate authority or permit subordinates to participate in policy making.

The results show that autocratic leadership has a negative significant impact on employee performance. This supports Jayasingam \& Cheng (2009) who stated that autocratic leaders dominate all actions and decisions all the while restricting the innovativeness and creativity of employees.

\section{Conclusions and Recommendations}

Autocratic leadership style, however, shows a significant negative impact on employee performance. This indicates that performance of employees would not increase when autocratic approach is applied. In view of globalization, autocratic leadership style may no longer be accepted by employees who are now becoming more knowledgeable, independent and competent. Most importantly, there is no mentorship process under autocratic leadership.

Job performance of subordinates is determined to a large extent by the leadership style adopted by the head librarians. It is therefore necessary for leaders to try and adopt the leadership style that will bring out the best in their subordinates. The average employee likes to be independent and does not want to work under conditions or coercion and compulsion. This type of behavior style, rather than solving organizational problems seems to create more problems. The Michigan studies also found that managers who adopted production-centered leadership style tended to have work groups that were less productive and employees showed a high degree of dissatisfaction on the job. Therefore, autocratic leaders tend to limit the performance of employees so posited by Puni, Ofei \& Okoe (2014) and Akor (2014).

Autocratic leadership style will in no way bring out the best in the subordinates. It is hereby recommended that the past records of those who are to be placed in position of leadership should be properly examined and serve as criteria for giving them the position if the objectives of the library in particular and that of the parent institution are to be actualized. Since autocratic leadership style leads to job dissatisfaction of subordinates, library heads should be closely monitored by the parent institution to check their excesses. There should also be retraining of those in leadership position and those who are equally aspiring to be leaders. Though autocratic leadership style may be very be valuable in situations where decisions need to be made as quickly and decisively as possible. Janse (2018) posited that authoritarian leadership is desired in the following situations: When employees do not do their job properly, either because of incompetence 
or inexperience, close monitoring and guidance is required. An authoritarian approach to lazy employees is generally very effective than when kindly asked if they want to perform certain tasks

\section{References}

[1] Aina, L.O. and Ajifenike, I.S.Y. (2002). Research Methodologies in Information Science. In: L.O. Aina Ed., Research in Information Sciences: An African Perspective. Ibadan: Sterling-Horden

[2] Ajibade, T.O. (2010). Principals' Leadership Styles and Teachers' Job Performance in Senior Secondary Schools in Ondo State, Nigeria. International Journal of Educational Administration and Policy Studies, 2 (6): 83-91. https://doi.org/10.5897/IJAPSIO.019 (accessed September 20, 2018).

[3] Akor, P. U. (2014). Influence of autocratic leadership style on the job performance of academic librarians in Benue State. Journal of Educational and Social Research, 4(7): 148-152.

[4] Amanchukwu, R. N., Stanley, G. J. \& Ololube, N. P. (2015). A Review of Leadership Theories, Principles and Styles and their Relevance to Educational Management. Management, 5(1): 6-14.

[5] Boehm, S. A., Dwertmann, D. J., Bruch, H. \& Shamir, B. (2015). The Missing Link? Investigating Organizational Identity Strength and Transformational Leadership Climate as Mechanisms That Connect CEO Charisma with Firm Performance. The Leadership Quarterly, 26(1): 156-171.

[6] Fatokun, J.O, Salaam, M.O, Ajebomogun, F. O and Adedipe, N. (2010). The Influence of Leadership Style on the Performance of subordinates in Nigeria libraries. Library Philosophy and Practice 2010. http://www.webpages.Uidaho.edu/mboblin/fatokun-salaam.ajebomogun.html (accessed September 20, 2018).

[7] Iqbal, N., Anwar, S. \& Haider, N., (2015). Effect of Leadership Style on Employee Performance. Arabian Journal of Business and Management Review, 5: 146.

[8] Janse, B. (2018). Authoritarian Leadership. Retrieved from Tools Hero: https://www.toolshero.com/leadership/authoritarian-leadership/ accessed September 20, 2018).

[9] Jayasingam, S. \& Cheng, M. Y. (2009). Leadership Style and Perception of Effectiveness: Enlightening Malaysian Managers. Asian Social Science, 5(2):54-65.

[10] John, C.M. (2002) Million Leaders Mandate Curriculum: Notebook One. USA: Equip Publishers.

[11] McLeod, S. (2008). Simply Psychology. [Online] Available at: https://www.simplypsychology.org/likert-scale.html (accessed September 20, 2018).

[12] Mgbodile, T. O. (2004). Fundamentals in Educational Administration and Planning. Magnet Business Enterprises: Enugu.

[13] Nwachukwu, C. (2010). Effective leadership and Productivity; Evidence From a National Survey of Industrial Organizations. African Journal for Study of Social Issues, 1: 38-46.

[14] Nwaigwe, U. (2015.) The Influence of Head Librarians' Leadership Styles on Job Satisfaction of Librarians in Tertiary Institution Libraries in Imo State, Nigeria. Open Access Library Journal 2, 1-9. Doi: 10.4236/oalib.1/01572 (accessed September 20, 2018).

[15] Puni, A., Ofei, S. B. \& Okoe, A., (2014). The Effect of Leadership Style on Firm Performance Ghana. International Journal of Marketing Studies, 6(1): 177-185.

[16] Stodgill, R.M. (1974) Handbook of Leadership: A Survey of Theory and Research. New York: The Free Press. https://www.jstor.org/stable/3790949 (accessed September 20, 2018).

[17] Vecchio, R. (2007) Leadership: Understanding the Dynamics of Power and Influence in Organizations, University of Notre Dame Press: Notre Dame.

[18] Zareen, M., Razzaq, K. \& Mujtaba, B., 2015. Impact of Transactional, Transformational and Laissez- Faire Leadership Styles on Motivation: A quantitative study of banking employees in Pakistan. Public Organization Review, 15(4): 531-549.

\footnotetext{
*Corresponding author.

E-mail address:nwedol@yahoo.com/nonyesil@yahoo.com
} 